\title{
SDS Gels, Antibodies, and their Uses in Studying the Cytoskeleton of Animal Cells
}

\author{
By \\ Mary Osborn*
}

The last few years have seen an explosion in the use of gels of all descriptions. In studying proteins, SDS ${ }^{a}$ polyacrylamide gels allow the characterization of polypeptides by molecular weight and isoelectric focusing gels characterization by charge. The combination of the two systems in high resolution two-dimensional gels has facilitated the study of individual proteins even in very complex mixtures. This revolution in the techniques available to study proteins has been accompanied also by the realization that gel electrophoresis is a very powerful tool in the field of nucleic acid chemistry, and that gels can be used both to separate nucleic acid fragments, and in sequence methods. The breadth of this field is well illustrated by the individual contributions presented at this meeting.

The first part of my talk will concentrate on the use of SDS gels not only to study polypeptide molecular weights, but also on available methods to further characterize proteins separated on such gels. In the second part of my talk I will discuss the production of antibodies to proteins purified from SDS gels, and finally studies in which these antibodies have been used to study the elements of the cytoskeleton of cells in tissue culture. Both aspects of this work have been carried out together with Klaus Weber, and in fact our first paper on SDS gels ${ }^{1)}$ represents the beginning of a collaboration that has now extended ten years.

\section{Protein structure and the use of SDS gels in the study of molecular weights}

Knowledge of the quaternary structure of proteins by biochemical techniques depends on two measurements, a) a reliable estimate of the molecular weight of the undenatured protein and b) estimation of the molecular weight of the polypeptide chain or chains which constitute the protein. In the early 1960s both measurements were often made by sedimentation equilibrium centrifugation, a method which is timeconsuming, demanding experimentally, and in particular requires choice of a value for the partial specific volume, v. Full denaturation i.e. dissembly into polypeptide chains is achieved by solvents like 6-8 M guanidine $\mathrm{HCl}$ in the presence of $\beta$-mercaptoethanol. Because of the increased density $\delta$ of these solvents the value of the partial specific volume of the protein $\mathbf{v}$ chosen is of major importance for the molecular weight of the polypeptide chains because of the expression $(1-\mathbf{v} \delta)$ in the final formula. In those days there were lengthy discussions how much $\mathbf{v}$ changes upon denaturation of the protein, and some laboratories believed in a strong change; others did not and there was general disagreement as to the resulting subunit

* Max Planck Institute for Biophysical chemistry, Goettingen, Federal Republic of Germany.

a) Abbreviation : SDS, sodium dodecyl sulfate. 
structure. Shapiro, Vinuela and Maizel $^{2)}$ realized that the introduction of a dissociating detergent such as SDS into a solid separating polyacrylamide gel might provide an easier way to estimate subunit molecular weight. We first used the method with aspartate transcarbamylase, ${ }^{3)}$ and found that the molecular weights obtained for the two polypeptide chains were in excellent agreement with protein sequence ${ }^{3)}$ and x-ray data, ${ }^{4}$ but not with earlier sedimentation studies. We were sufficiently intrigued by these results to ask how widely applicable and how accurate the method might be. We therefore selected some 40 well-characterized proteins, and as shown in Fig. 1 were able to show that when the electrophoretic mobilities were plotted against the logarithm of the known polypeptide molecular weights a smooth curve was obtained. ${ }^{1)}$ It is worth mentioning that the subunit molecular weight of each of these proteins had been determined by protein sequence, by $x$-ray crystallography or by careful sedimentation equilibrium studies in more than one laboratory, and therefore this study showed that molecular weight could be determined in the range $14,000-200,000$ with an accuracy of at least $\pm 10 \%$.

Other advantages were also immediately apparent, i. e. the procedure required small amounts of proteins, did not depend to a first approximation on the isoelectric point of the proteins or the amino acid composition, was easy to do, and required only simple equipment. For these reasons it was not surprising that the method was rapidly adopted as the method of choice for determining polypeptide molecular weights, so that by 1975 it was possible to list the quaternary structure of some 300 proteins. ${ }^{52}$

Of course other studies ${ }^{6)}$ and improvements in the technique soon followed: Laemmlir) and Maizel ${ }^{8)}$ adapted the Tris-glycine buffer of Ornstein and Davis to SDS gels which provided sharper bands and improved separation of mixtures of polypeptides. SDS slab gels were introduced ${ }^{9)}$ with the advantages that even smaller amounts of proteins could be used, and that samples in adjacent slots could be more easily compared. Autoradiography not only further increased the sensitivity but also allowed quantitation of the data. Swank and Munkres ${ }^{10}$ extended the molecular weight range in which reliable molecular weights could be obtained to below 4,000 daltons by the inclusion of urea in the buffer. Thus currently the only molecular weight range in which it is difficult to establish an accurate molecular weight is above

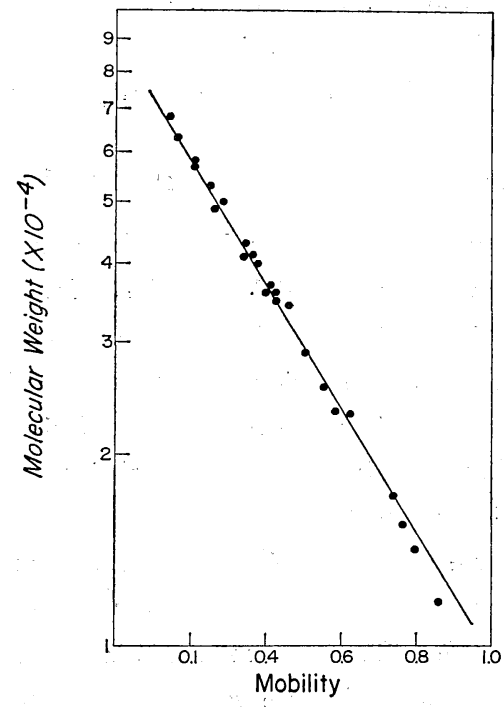

Fig. 1. Molecular weights of marker proteins plotted as a function of their electrophoretic mobilities on SDS polyacrylamide gels (for further details see ref. ${ }^{1,11}$ ). 
200, 000 daltons, where there are still insufficient well-characterized and commercially available standards. Anomalously behaving proteins, such as for instance those that contain large amounts of carbohydrate or those that have very unusual amino acid compositions, can often be recognized by running gels of different porosities. ${ }^{11,12)}$

The empirically established relationship between electrophoretic mobility and polypeptide chain molecular weight indicates that for protein SDS complexes the charge per unit mass is approximately constant, and also that the ratio of the effective charge to the frictional coefficient is approximately constant and independent of the molecular weight. Experimental work on model protein-SDS complexes ${ }^{13)}$ supports these ideas, and the usual assumption is that the complexes behave as prolate ellipsoids or rods, with the long axis varying in proportion to the molecular weight of the polypeptide chain.

\section{Multicomponent Systems}

A major advantage of the SDS gel technique is its use to study multicomponent systems. Thus complex proteins, viruses, ribosomes, membrane preparations and cell extracts can be resolved by SDS gels into their component polypeptides. Each polypeptide occurs at one, and only one place on the gel at a position corresponding to its subunit molecular weight. Thus if the gel is stained, the amount of protein can be determined by scanning the gel and the stochiometric relationship of components in a multicomponent system can be determined. Some of the earliest multichain proteins for which the stochiometry was determined in this manner include RNA polymerase (subunit structure $\alpha_{2} \beta \beta^{\prime}$ ), ${ }^{14}$ ) $Q \beta$-replicase (four subunits ${ }^{15)}$ including the protein biosynthesis factors $\mathrm{Tu}$ and $\mathrm{Ts}{ }^{16}{ }^{16}$ and aspartate transcarbamylase (subunit structure $\left.\mathrm{R}_{6} \mathrm{C}_{6}\right){ }^{3,17}$ ) Sometimes unexpected results are obtained-for example when myosin was first used as a standard on SDS gels ${ }^{1)}$ we were surprised to see not only the well-known heavy chains (molecular weight 220,000 daltons) but also the light chains which were known from other procedures ${ }^{18)}$ (molecular weight 16,000-20,000 daltons).

An independent procedure for the determination of subunit structures of oligomeric enzymes which also uses SDS gels was developed by Davies and Stark. ${ }^{19)}$ Using the bifunctional reagent dimethyl subrimidate they showed that cross linking occurs predominantly within oligomers, and thus after cross linking and SDS gel electrophoresis a set of species with molecular weights equal to integral multiples of the molecular weight of the polypeptide chain is seen. This is illustrated in Fig. 2.

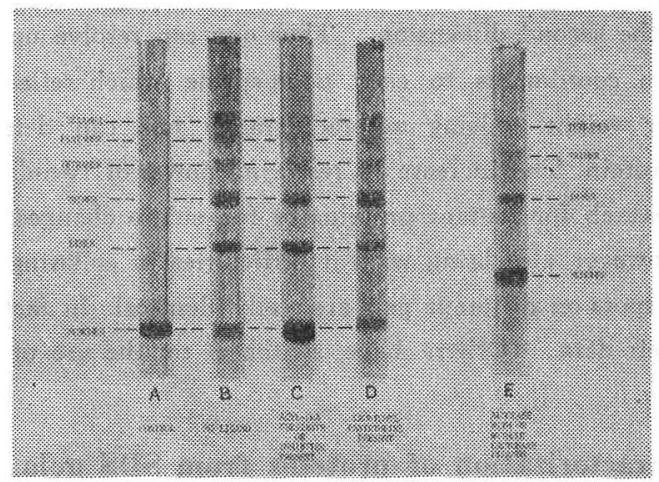

Fig. 2. SDS gel patterns of oligomeric enzymes cross linked with diethylsuberimidate. Gels A-D show the hexameric enzyme crotonase, gel $\mathrm{E}$ the tetrameric enzyme aldolase. Picture kindly provided by R. M. Waterson (for further details see ref. ${ }^{11)}$ ). 
This sort of analysis can also of course be applied to systems containing large numbers of components. For example Fig. 3 shows SDS gels of different viruses which after purification have been treated with SDS and mercaptoethanol. Gel (a) shows the capsid proteins of the bacteriophage R 17.20) i. e. the major capsid protein, molecular weight 14,000, and the minor component, the A-protein, molecular weight 38,000 present in one copy per virion. Gel (b) shows proteins of the bacteriophage $Q \beta$; the additional protein here is due to a leaky stop signal at the end of the coat protein gene. ${ }^{21}$ ) Gel (c) shows the proteins of encephalomyocarditis virus, which has three capsid proteins present in approximately equal amounts, ${ }^{22}$ and (d) shows the capsid proteins of $T_{4}$ where more than 20 proteins are visible. ${ }^{7)}$

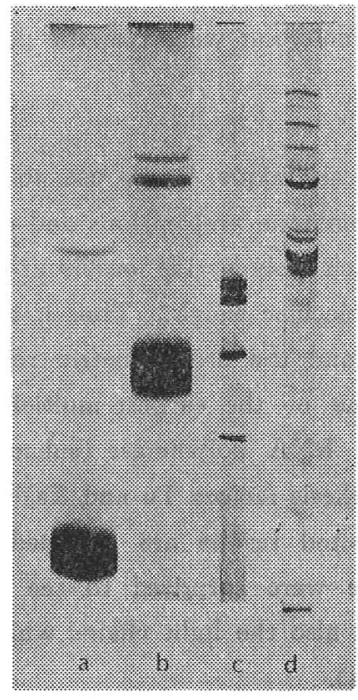

Fig. 3. SDS gel electrophoresis of different purified viral preparations showing viral coat, and other viral proteins. (a) E. coli phage $\mathrm{R} 17$, (b) E. coli phage $\mathrm{Q} \beta$, (c) Encephelomyocarditis virus (EMC), (d) T 4 bacteriophage (for further details see ref. ${ }^{11)}$ ).

\section{High resolution two-dimensional gels}

O'Farrell ${ }^{23)}$ has shown that it is possible to combine isoelectric focusing in the first dimension with SDS gel electrophoresis in the second dimension. Thus one can resolve up to 1,100 proteins present in an $E$. coli extract, and assign coordinates to each polypeptide which reflect the isoelectric point of the polypeptide and its molecular weight. Using autoradiography one can detect proteins which constitute $10^{-4}$ to $10^{-5} \%$ of the total protein. The increase in resolving power of two-dimensional gels is of course of enormous advantage in the search for mutant proteins or for subtle changes accompanying differentiation or development. ${ }^{24}$ ) It does however also bring with it difficulties in collating all the information each gel contains, and in deciding if spots on different gels are really identical. In fact some 2D-gel users now feel compelled to computerize their data. Others have switched to the use of color photography to record subtle differences in intensity.

\section{Methods for further characterization of proteins from SDS gels}

Often when individual polypeptides have been separated on SDS gels in order to characterize them further, and in particular to establish their similarity or difference to other known proteins of equivalent molecular weight, it is necessary to obtain further information. Thus procedures have been developed 
that allow amino acid analysis of polypeptides directly from gels ${ }^{25}$ and that allow SDS to be removed from proteins ${ }^{26,27)}$ so that in some cases, as shown in Table 1 , biological activity can be recovered. ${ }^{26)}$ Procedures also exist which after elution of the polypeptide from the gel allow peptide mapping either on paper, or by partial digestion and rerunning on a second SDS gel. ${ }^{28}$ ) Polypeptides can also be characterized by amino terminal sequence analysis from gels, ${ }^{29}$ as shown in the next Table 2. Carbohydrate-containing proteins can be identified by several techniques directly on the gel. ${ }^{30}$ ) All of these procedures can provide information which is of value in characterizing an unknown protein.

Furthermore if one possesses an antibody to a particular component one can use the antibody to identify the component of interest in a multicomponent system, for example in a cell extract. An example of the immune-replica-technique ${ }^{31)}$ is shown. Antiserum is incorporated into an agarose overlay which is placed over an SDS polyacrylamide slab gel. After washing the gel, immunoprecipitated proteins can be visualized either with coomassie blue or with iodinated protein $A,{ }^{32)}$ and thus the band reacting with the antiserum can be identified.

A further use of antibodies is in separating the corresponding antigen from a complex mixture. Thus after formation of an antigen-antibody complex it can be spun out and separated into its component

Table 1. Recovery of enzymes from SDS polyacrylamide gels. For further details see ref. ${ }^{26)}$

\begin{tabular}{|c|c|c|}
\hline Protein & $\begin{array}{c}\text { Applied to gel } \\
(\mu \mathrm{g})\end{array}$ & $\begin{array}{c}\text { Recovery } \\
(\%)\end{array}$ \\
\hline \multicolumn{3}{|c|}{$\begin{array}{l}\text { Aspartate transcarbamylase } \\
\text { (catalytic subunit) }\end{array}$} \\
\hline Experiment 1 & $\begin{array}{r}280 \\
150 \\
55 \\
20\end{array}$ & $\begin{array}{l}36 \\
13 \\
16 \\
46\end{array}$ \\
\hline Experiment 2 & $\begin{array}{r}280 \\
140 \\
70 \\
28\end{array}$ & $\begin{array}{l}25 \\
55 \\
50 \\
67\end{array}$ \\
\hline Experiment 3 & $\begin{array}{r}250 \\
150 \\
50 \\
20\end{array}$ & $\begin{array}{l}40 \\
20 \\
25 \\
60\end{array}$ \\
\hline Experiment 4 & $\begin{array}{l}140 \\
140 \\
140 \\
140\end{array}$ & $\begin{array}{l}24 \\
29 \\
22 \\
14\end{array}$ \\
\hline Experiment 5 & $\begin{array}{l}140 \\
140 \\
140\end{array}$ & $\begin{array}{l}11 \\
19 \\
14\end{array}$ \\
\hline \multicolumn{3}{|l|}{ Aldolase } \\
\hline Experiment 1 & $\begin{array}{r}200 \\
100 \\
35\end{array}$ & $\begin{array}{l}15 \\
19 \\
25\end{array}$ \\
\hline \multicolumn{3}{|l|}{$L a c$ repressor } \\
\hline Experiment 1 & $\begin{array}{l}450 \\
270\end{array}$ & $\begin{array}{l}11 \\
25\end{array}$ \\
\hline Experiment 2 & $\begin{array}{r}450 \\
360 \\
90\end{array}$ & $\begin{array}{r}4 \\
5 \\
15\end{array}$ \\
\hline \multicolumn{3}{|c|}{$\sigma$ factor of RNA-polymerase } \\
\hline Experiment 1 & 100 & 60 \\
\hline Experiment 2 & 40 & 50 \\
\hline
\end{tabular}


Table 2. Amino terminal sequences obtained with the SDS dansyl Edman technique. For further details and comparison of these sequences with those obtained by other methods see ref. ${ }^{29}$

\begin{tabular}{|c|c|c|c|c|}
\hline Protein & & & Mol. wt. & Amino-terminal sequence \\
\hline \multicolumn{5}{|l|}{ From E. coli } \\
\hline$\beta$-Galactosidase & 3 & 390 & 135,000 & Thr-Met-Ile-Thr-Asx-Ser-Leu-Ala \\
\hline Lac repressor & & & 38,000 & $\begin{array}{l}\text { Met-Lys-Pro-Val-Thr-Leu-Tyr-Asx- } \\
\text { Val-Ala-Glx-Tyr-Ala-Gly-Val-Ser }\end{array}$ \\
\hline Aspartate transcarbamylase catalytic subunit & 3 & 100 & 33,000 & Ala-Asx-Pro-Leu-Tyr-Glx-Lys-Ile-Ile \\
\hline Tryptophan synthetase A protein & 1.2 & 36 & 29,000 & Met-Glx-Arg-Tyr \\
\hline Minor capsid proteins from RNA coliphage & & & & \\
\hline R17 maturation protein & & & 38,000 & Met-Arg-Ala-Phe-Ser-Ala-Leu-Asx \\
\hline $\mathrm{Q} \beta$ maturation protein (IIa) & 1 & 40 & 41,000 & Pro-Lys-Leu-Pro \\
\hline $\mathrm{Q} \beta$ read-through protein (IIb) & 3 & 100 & 36,000 & Ala-Lys-Leu-Glx-Thr-Val-Thr-Leu \\
\hline \multicolumn{5}{|l|}{ Major capsid proteins from RNA coliphage } \\
\hline R17 coat protein & 5 & 70 & 14,000 & $\begin{array}{l}\text { Ala-Ser-Asx-Phe-Thr-Glx-Phe-Val- } \\
\text { Leu-Val }\end{array}$ \\
\hline $\mathrm{Q} \beta$ coat protein & 5 & 70 & 14,000 & Ala-Lys-Leu-Glx-Thr-Val-Thr-Leu \\
\hline \multicolumn{5}{|l|}{ Other proteins } \\
\hline $\mathrm{Q} \beta$ replicase subunit II & 0.7 & 45 & 64,000 & Ser-Lys-Thr-Ala \\
\hline Hen egg white lysozyme & 0.35 & 5 & 14,000 & Lys-Val-Phe-Gly \\
\hline
\end{tabular}

polypeptides by heating with SDS and mercaptoethanol. This sort of approach has been used to isolate mutant lac repressor polypeptides lacking the $\mathrm{N}$-terminal protein of the molecule. ${ }^{33}$ It is of particular use when only small amounts of antigen are present, and this approach has also been used extensively in virology - for example in the study of early viral antigens. ${ }^{34}$

\section{Antibodies to proteins separated on SDS gels}

SDS gels can often be used as the final step in the purification of individual polypeptides that are hard to separate by normal techniques. Further characterization of the protein can be obtained by some of the methods already mentioned, and it is often possible to demonstrate that one has purified a unique polypeptide. Under such circumstances the separated protein can be eluted, recovered and used as an antigen to elicit antibodies. Production of antibodies to SDS-denatured proteins has been used by a number of investigators, and one of the earlier reports is that of Roberts ${ }^{35)}$ who succeeded in raising an antibody to SDS-denatured glutamate dehydrogenase from Neurospora Crassa. This cross-reacted with both the denatured and the native enzyme. A similar finding was also made at about the same time by Rosenbusch and Weber, who showed that antibodies to several SDS-denatured proteins from E. coli crossreacted with the native molecules. Exploting these findings, Lazarides and Weber ${ }^{36)}$ succeeded in 1974 in raising an antibody to actin from mouse 3T3 cells by first denaturing it with SDS, and showed how powerful the study of cellular structure could be when specific antibodies are used in conjunction with immunofluorescence microscopy. It is this aspect of the use of SDS gels that has occupied most of our recent efforts, and in the remainder of my talk I want to describe work which Klaus Weber and I have done on the cytoskeleton of animal cells in the last five years. 


\section{The cytoskeletal proteins are major components of animal cells}

If one runs one- or two-dimensional gels of E.coli on the one hand, and of tissue culture cells grown in vitro on the other hand, and begins to identify some of the major polypeptides present, there are striking differences. Whereas the predominant polypeptides in the case of E.coli are the protein biosynthesis elongation-factors $\mathrm{G}, \mathrm{Tu}, \mathrm{Ts}$ and the ribosomal proteins, in the case of mammalian cells the major components are not elements of the protein synthesizing machinery but are instead the subunits of the fibrous elements of cells, i.e. actin, the subunit of microfilaments, molecular weight 43,000 ; tubulin the subunit of microtubules, molecular weights of the $\alpha$ - and $\beta$-chains 55,000 and 56,000 daltons, and then in addition the subunit of the $100 \AA$ filaments (Fig. 4). In addition, as of course expected, the histones are major cellular protein components. This can be demonstrated even more strikingly in cells treated with a nonionic detergent. ${ }^{37}$ Fig. 4 shows that for chick embryo fibroblasts, actin and the $100 \AA$ polypeptide are retained in the cytoskeleton, whereas under these conditions tubulin is not retained. ${ }^{37}$ ) This predominance of cytoskeletal proteins suggests that the organization of the cytoplasm is of a fundamental, and as yet not fully understood importance in the existence of the mammalian cell.

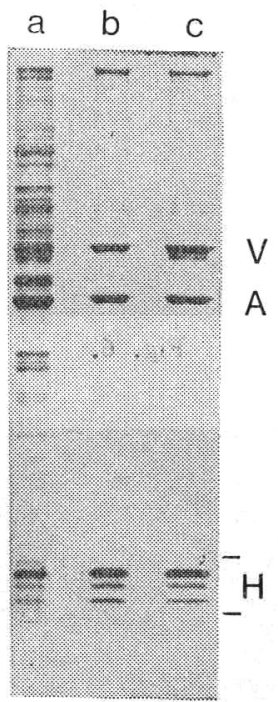

Fig. 4. SDS polyacrylamide gel electrophoresis of whole chick cells (a), and of cytoskeletons prepared from chick cells (b and c). The position of actin (A) and of the histones (H) is marked. In (c) purified tubulin has been added to the gel to show that the band marked $\mathrm{V}$ corresponds to vimentin, the major subunit of the $100 \AA$ filaments in these cells, and not to tubulin. For further details see ref. ${ }^{37}$

\section{Immunofluorescence microscopy}

This technique was pioneered by Coons, ${ }^{38)}$ and is illustrated in Table 3. It involves three steps. First fixation with formaldehyde or sometimes glutaraldehyde. Second making holes in the cell membrane so the antibodies can get into the cell. Thirdly the specific antibody itself is added, for example actin antibody. Then to visualize the actin antibody, since the antibody was made in rabbits, a fluoresceinlabeled second antibody, goat-anti-rabbit IgG, is added. After further washing the cells are viewed in a 


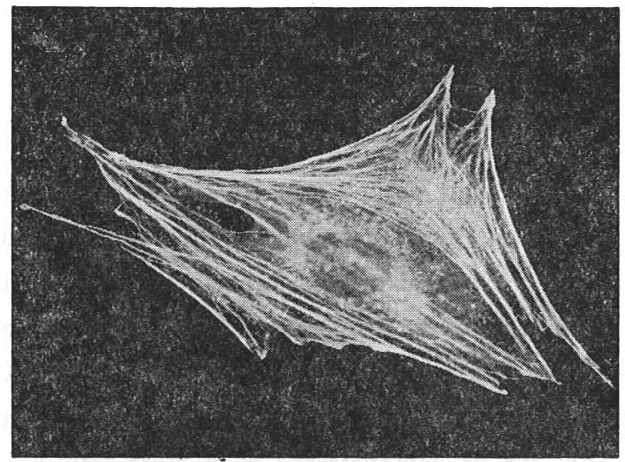

Fig. 5.

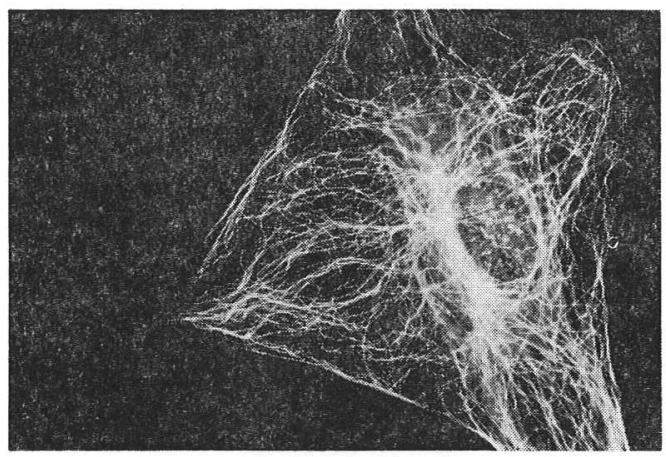

Fig. 6.

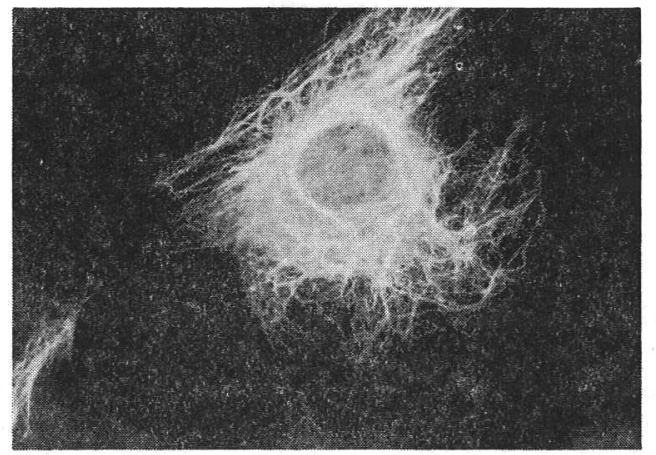

Fig. 7.

Fig. 5, 6, 7. 3T3 cells reacted either with specific antibodies raised against (Fig. 5) actin from chicken gizzard which stains microfilaments (Fig. 6) tubulin from pig brain which stains cytoplasmic microtubules and (Fig. 7) vimentin isolated from $3 \mathrm{~T} 3$ cells which stains the $100 \AA$ filament system. Note the different appearance of these three fiber systems when viewed by immunofluorescence microscopy. 
Table 3. Immunofluorescence.

1. Fixation either with glutaraldehyde or formaldehyde followed in both cases by organic solvents to make holes in the cell membrane, or with organic golvents slone.

2. Application of 1 st antibody (e.g. anti-actin made in rabbits).

Incubate 45 minutes at $37^{\circ} \mathrm{C}$, wash.

3. Application of 2 nd antibody (e.g. fluorescein labeled goat anti-rabbit globulins).

Incubate 30 minutes at $37^{\circ} \mathrm{C}$, wash.

4. Mount and examine in fluorescence microscope. (in the example given only actin containing structures should be fluorescent).

fluorescence microscope. We use the indirect technique for two reasons, (a) It does not require labeling of the experimentally produced antibody with possible loss of valuable material, (b) it is more sensitive than the direct technique.

The pictures obtained look a little different from the more conventional views of cells obtained with scanning electron microscopy or with conventional thin section electron microscopy in which microfilaments ( $60 \AA$ diameter), microtubules ( $250 \AA$ diameter) and $100 \AA$ filaments can often be identified. The same three systems viewed in immunofluorescence microscopy with antibodies to actin (Fig. 5), tubulin (Fig. 6) and to a particular type of $100 \AA$ filaments (Fig. 7) are shown in the figures. These figures show some of the advantages of immunofluorescence microscopy, i. e. that only the system of choice is viewed, that one obtains an overview over the whole cell, and that one can study numerous cells simultaneously.

\section{Antibody to actin and to the microfilament-associated proteins}

In this case use of SDS-denatured actin as an antigen was important in eliciting an antibody. The antibody reacted with SDS-denatured and with native actin in immunodiffusion, and antibodies specific for actin could be isolated from the pool. When it was used on cells in tissue culture it was immediately clear that different cells have different actin arrangements. ${ }^{39)}$ The most striking actin-containing structures characteristic of certain cell types such as fibroblasts are the stress fibers ${ }^{36}$ ) which are also visible in phase microscopy ${ }^{39)}$ (Fig. 8). That stress fibers contain F-actin was known from the work of Ishikawa et al. ${ }^{40)}$ using heavy meromyosin decoration in the electron microscope. Transformation of cells by viruses often reduces the number and thickness of the stress fibers present. ${ }^{41}$. When such cells are stained, actin often appears to be present as surface protrusions (Fig. 9), and the data suggests that the particular arrangement of actin present in cells may reflect the cell shape and how well the cell is spread on the substratum. ${ }^{42)}$ There is currently no hint as to whether the two different cytoplasmic actins ( $\beta$ and $\gamma$ ) which can be distinguished by isoelectric focusing, ${ }^{43)}$ or by primary sequence, ${ }^{44)}$ play different structural roles in the cell.

It has also been possible to construct a "protein chemical anatomy" of the stress fiber. Thus it has been possible to show that some antibodies, e. g. those to actin and filamin ${ }^{45}$ stain the stress fiber in an uninterrupted fashion, whereas antibodies to others, e. g. myosin, ${ }^{46)} \alpha$-actinin ${ }^{475}$ and tropomyosin ${ }^{48)}$ do so in a discontinuous, or striated, fashion (Fig. 10). Use of two antibodies simultaneously has shown that some of the microfilament-associated proteins may be arranged along the stress fiber in a mutually exclusive fashion. ${ }^{47,49)}$ Recent studies have suggested that many of the microfilament-associated proteins are found in a shell lying underneath the upper and lower plasma membrane and have produced three-dimensional electron micrographs of the lattice which runs throughout the cell. Some fibrous components of the lattice can be identified using ferritin-labeled antibodies, ${ }^{50)}$ and may be related to the microtrabeculae 


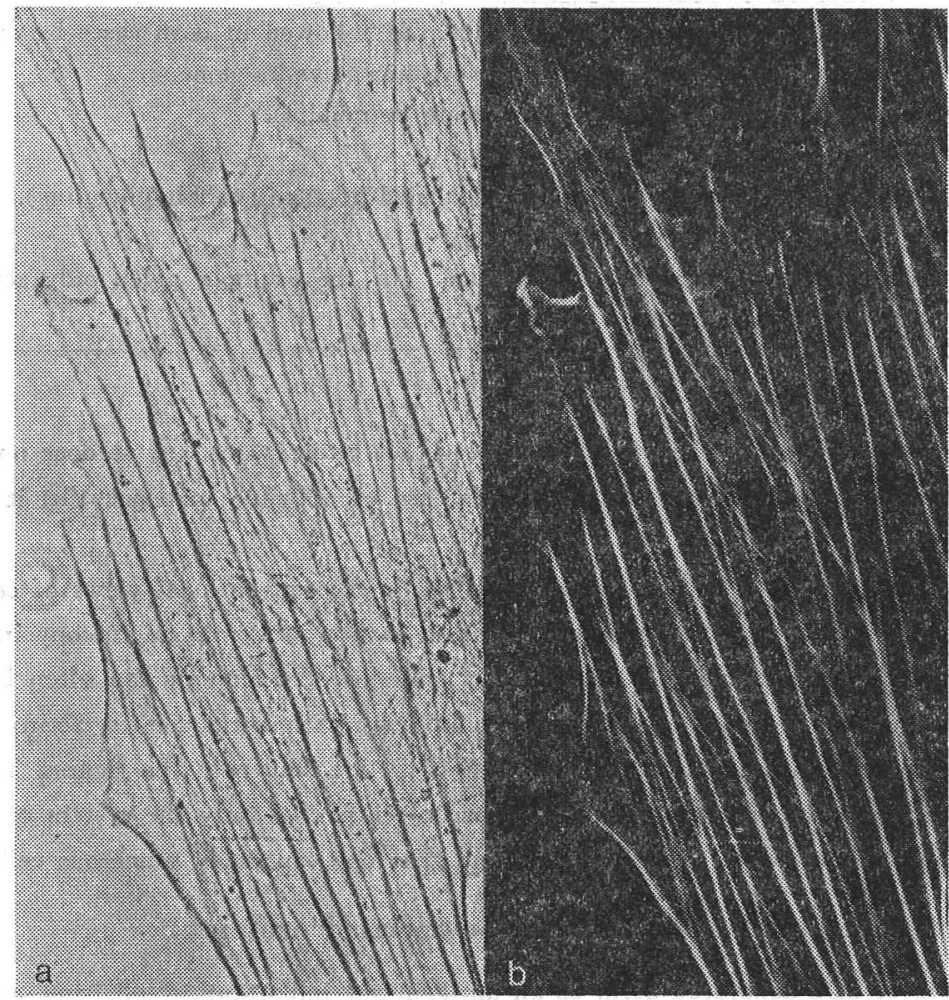

Fig. 8. Comparison of the stress fibers in rat mammary cells viewed either in phase (a) or after decoration with actin antibody. (b) Note the 1:1 correspondence.

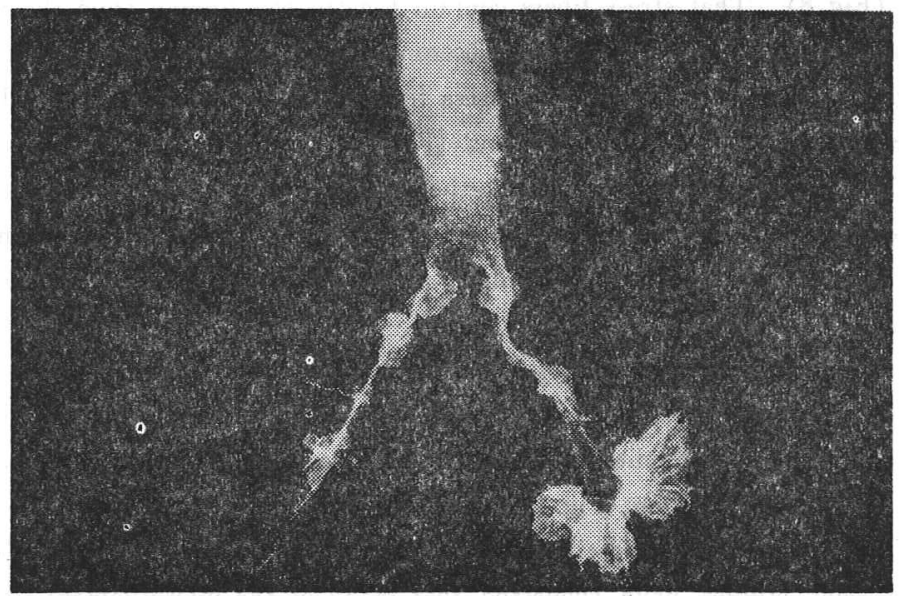

Fig. 9. A neuroblastoma cell stained with antibody to actin. 


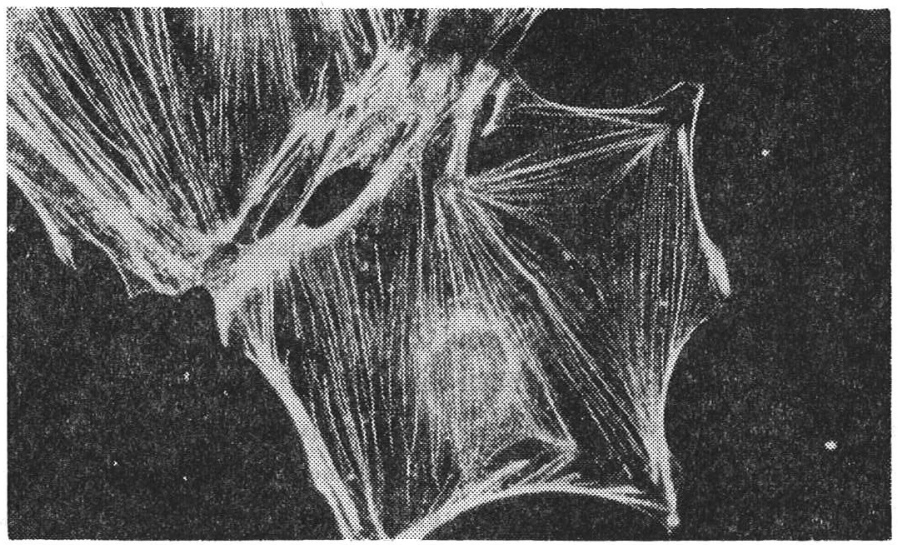

Fig. 10. PtK2 cell stained with antibody to myosin. Note the staining of the stress fibers is not continuous but is interrrupted (cf. Fig. 8). For further details see ref.46)

described by Wolosewick and Porter. ${ }^{51)}$ This submembraneous sheath and the three-dimensional lattice is assumed to be involved in cell movement because of experiments both with cytochalasin and with the actin-specific drug phalloidin. ${ }^{53)}$ Both drugs affect actin polymers in the cell. In the case of cytochala$\sin ^{52)}$ the stress fibers become arborized as shown in Fig. 11. When phalloidin is added to cells in culture, new actin aggregates are seen and in addition both cell division and cell movement is stopped in a concentration-dependent manner. ${ }^{54)}$ A recent study of dividing cells by immunofluorescence microscopy ${ }^{55)}$ supports the idea that actin and some of the other microfilament-associated proteins are involved in contractile ring formation ${ }^{55,56)}$ i.e. in the cleavage of the cell cytoplasm into two parts. However contrary to published reports, ${ }^{56)}$ we find no evidence that these proteins form major fibrous elemets of the mitotic spindle. However our immunofluorescence results are consistent with experiments by Mabuchi and Okuno $^{57)}$ on sea urchin eggs in which injection of antibody to myosin stops cytokinesis but not chromosome movement.

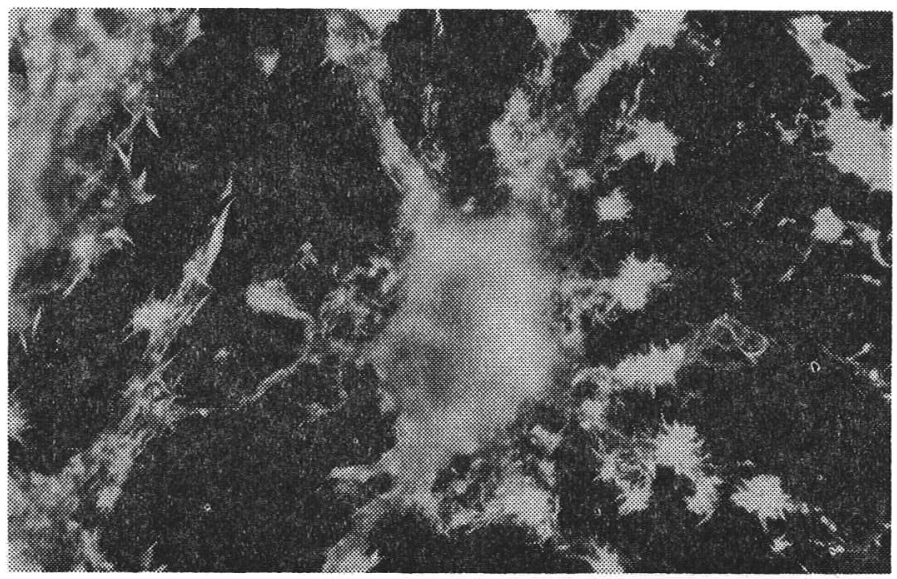

Fig. 11. 3T3 cells treated with cytochalasin B and then stained with antibody to actin. Note that cytochalasin disrupts the stress fibers normally present in this cell line (cf. Fig. 5). For further details see ref. ${ }^{52)}$ 


\section{Antibody to tubulin}

The use of antibodies to tubulin on cells in tissue culture has revealed the complex arrays of cytoplasmic microtubules present in interphase cells, and allowed their response to differing conditions and to drugs to be studied ${ }^{58 \sim 60)}$ (for a review see ref.). ${ }^{61)}$ They are particularly impressive when viewed in stereo immunofluorescence microscopy. ${ }^{62}$ ) An example of cytoplasmic microtubules in 3T3 cells is shown in the next figure (Fig. 12). Notice that this looks very different to the actin cables, and that the microtubules are of constant diameter, are unbroken, and can often be traced for long distances between the nuclear membrane and the plasma membrane. When the initial pictures of cytoplasmic microtubules viewed by the immunofluorescent technique were published ${ }^{58}$ there was controversy over whether immunofluorescence microscopy could reveal individual microtubules (diameters $250 \AA$ ), even though Kuriyama and Miki-Nomura ${ }^{63)}$ had already shown that single microtubules could be visualized in dark field microscopy. We were able to settle this problem, by treating cells with tubulin antibody and then viewing the same cell first in immunofluorescence microscopy and then, after staining with uranyl acetate, in electron microscopy. ${ }^{64)}$ This is shown in Fig. 13. Comparison of the images shows that wherever a fluorescent fiber is present, a corresponding fiber of diameter $550 \AA$ is seen in the electron micrograph. This is the diameter expected for a single microtubule decorated around its circumference with two layers of antibodies in the indirect technique (Table 4). Our studies show extensive cytoplasmic microtubular networks also in transformed cells, ${ }^{65)}$ a finding that in spite of initial disagreement ${ }^{60}$ ) has been confirmed in several other studies.66) In addition it has also proved possible to construct a protein chemical anatomy also of the microtubule, and to show not only that tubulin is present, but also that tau ${ }^{67)}$ (molecular weight 55, 000-60,000 daltons) and the high molecular weight microtubule-associated proteins ${ }^{68}$ ) (molecular weight $>300,000$ daltons) are integral components of the cytoplasmic microtubules. One can also use immunofluorescence microscopy to ask other types of questions. Thus if one uses colcemid to depolymerize the cytoplasmic microtubules, ${ }^{69}$ ) one can ask how, and in what direction, do the microtubules regrow? This is shown in Fig. 14 as a function of time after removal of colcemid. The microtubules appear to regrow from the perinuclear area towards the plasma membrane. This data, and other similar approaches, focus attention on to the centrioles, and on the possible functions of microtubules as direction markers

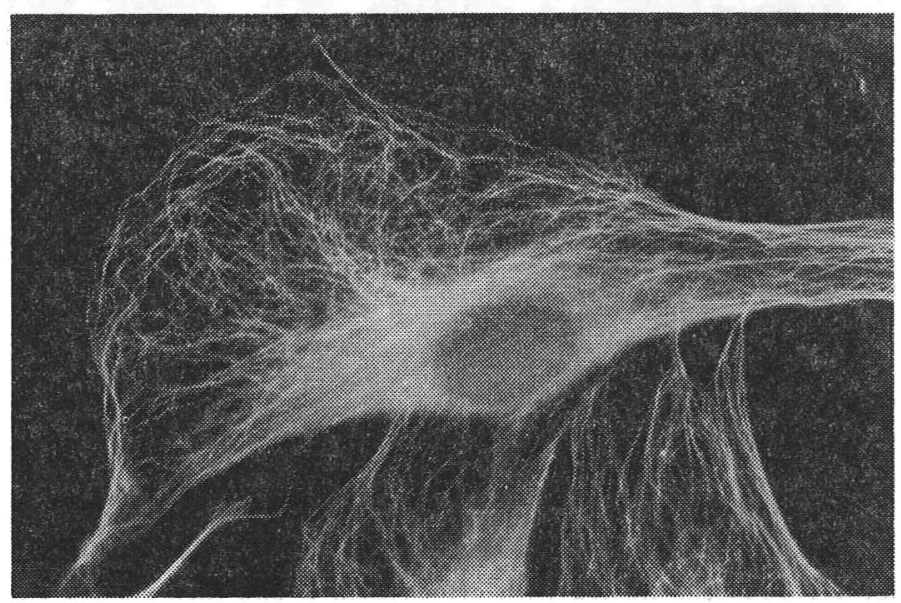

Fig. 12. Cytoplasmic microtubules in 3 T3 cells viewed after treatment of the cells with glutaraldehyde, and staining with tubulin specific antibody. For further details see ref. ${ }^{61)}$ 


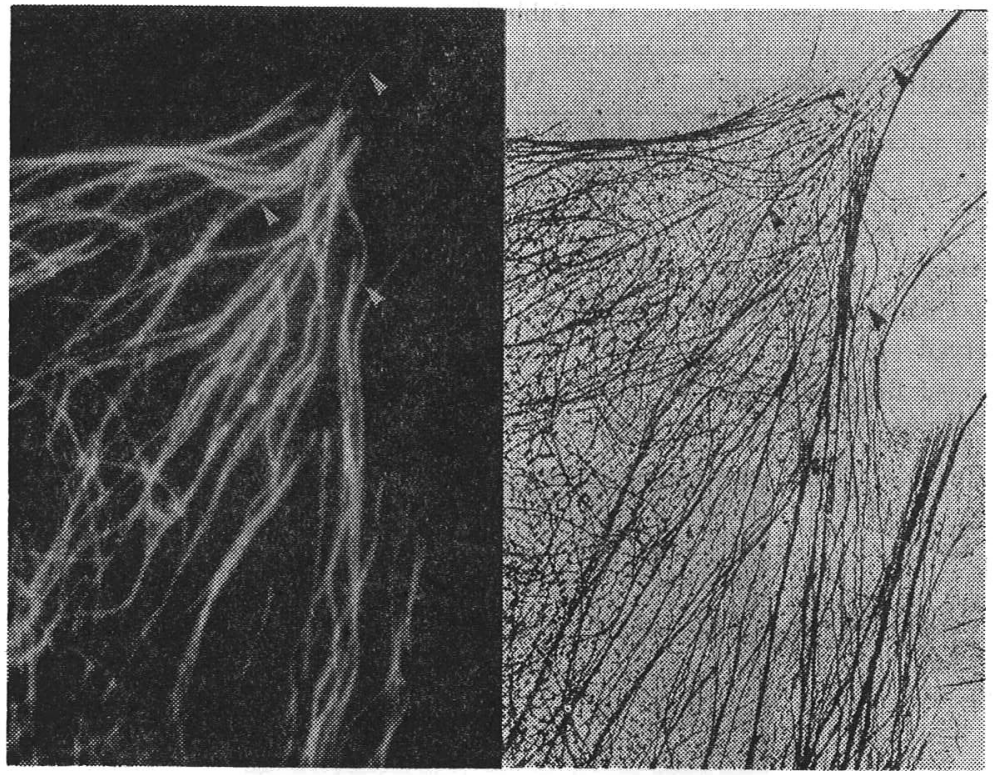

Fig. 13. The same Ptk2 cell viewed (a) in immunofluorescence microscopy (b) in electron microscopy after staining with tubulin antibody. For further details see ref. ${ }^{61,64)}$

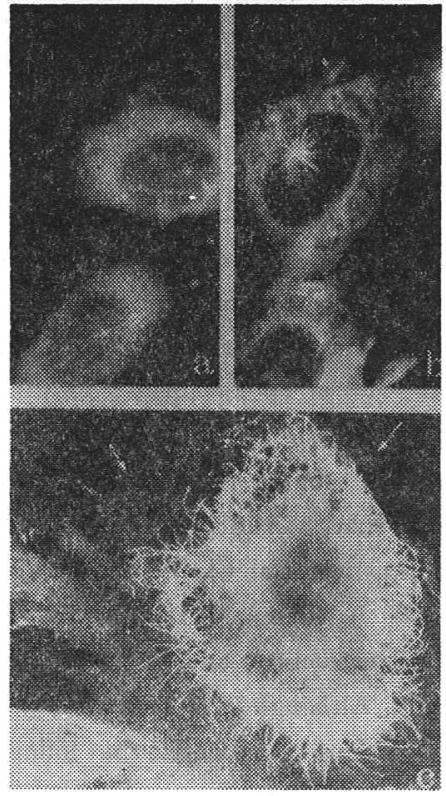

Fig. 14. Regrowth of cytoplasmic microtubules after treatment of 3T3 cells with colcemid. Times in drug free medium are (a) 0 minutes, (b) 35 minutes, (c) 50 minutes. Note the reappearance of microtubules at a particular place in the cells and that in (c) the microtubules extend only part way across the cell. (for further details see ref. ${ }^{69)}$ ). 
Table 4.

\begin{tabular}{c|c|c}
\hline \hline Microtubular diameters & With control IgG & With tubulin IgG \\
\hline Electron microscopy & & \\
Observed in thin sections & $250 \AA$ & $600 \AA$ \\
in cytoskeletons & $220 \AA$ & $550 \AA$ \\
Expected it IgG diameter $90 \AA$ & $220 \AA$ & $\sim 580 \AA$ \\
Fluorescence microscopy & & \\
Observed & & $2,000 \AA-2,500 \mathrm{~A}$ \\
Expected limit of resolution & & $\sim 2,000 \mathrm{~A}$ \\
\hline
\end{tabular}

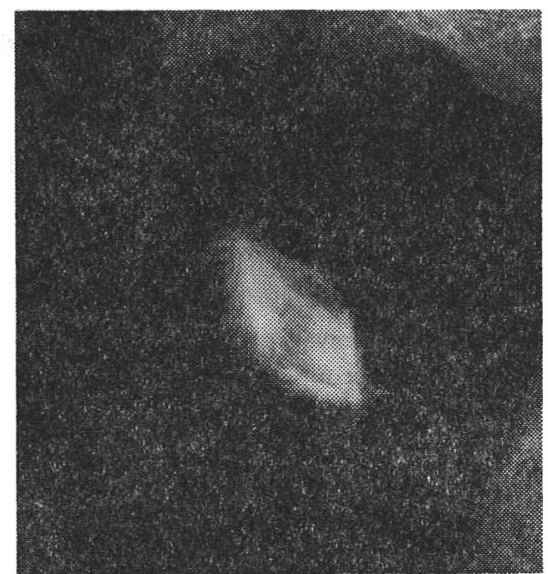

Fig. 15. A metaphase cell stained with antibody against tubulin. For other mitotic stages see ref. ${ }^{71}$

within the cell. $\left.{ }^{69}, 70\right)$ Perhaps they convey signals, or are used in the intracellular transport of material inside the cell. In mitosis the cytoplasmic microtubules are depolymerized and immunofluorescence microscopy with tubulin antibody reveals the different stages in the formation of the mitotic spindle ${ }^{71}$ (Fig. 15). The molecular events which trigger mitosis are still largely unknown.

\section{Antibody to $100 \AA$ filaments}

The different antibodies to actin and tubulin react over a wide species range, in agreement with ultrastructural studies which have shown that microfilaments and microtubules have constant ultrastructural features in a wide variety of experimental material (Table 5). Although initially it was expected that a similar situation might occur when $100 \AA$ filaments were studied, it has become increasingly apparent that in spite of similarities in the ultrastructure and in vitro behaviour of reconstituted filaments ${ }^{72}$ certain subgroups can be distinguished. Although the data is far from complete, if one considers the work from several laboratories ${ }^{73 \sim 75)}$ it appears as though the following subgroups can be distinguished immunologically. Our work on intermediate filaments has been carried out in collaboration with Werner Franke.

1) The intermediate filaments characteristic of fibroblasts ${ }^{76)}$ and other cells of mesenchymal origin. ${ }^{73,75)}$ The subunit has a polypeptide molecular weight of 57,000, for which we have proposed the name "vimentin." ${ }^{75)}$ Vimentin-type filaments can be recognized using sera prepared against this protein purified on SDS gels, and as shown in Fig. 16 when used in the immune replica technique, ${ }^{31,32)}$ the antibody can be 
Table 5. Classes of intermediate filaments.

\begin{tabular}{|c|c|c|c|}
\hline Cell type in situ & Protein & Examples & Cell types in vitro \\
\hline 1. Epithelia & (pre) keratin & $\begin{array}{l}\text { keratinizing } \\
\text { and no keratinizing } \\
\text { epithelia }\end{array}$ & Hela, $\mathrm{CV}_{1}, \mathrm{PtK}_{1}, \mathrm{PtK}_{2}$ \\
\hline 2. Mesenchymal cells & $\begin{array}{l}\text { "vimentin" } \\
57 \mathrm{~K}\end{array}$ & $\begin{array}{l}\text { fibroblasts } \\
\text { chondrocytes } \\
\text { endothelial cells } \\
\text { macrophages }\end{array}$ & "all" established cell lines \\
\hline 3. Muscle & $\begin{array}{l}\text { "desmin" } \\
53 \mathrm{~K}\end{array}$ & $\begin{array}{l}\text { smooth, heart } \\
\text { skeletal muscle }\end{array}$ & muscle differentiation in vitro \\
\hline 4. Neuronal & neurofilament & & \\
\hline 5. Glia (Astrocytes) & glia fibrill. a. prot. & & U. 251 MG \\
\hline
\end{tabular}

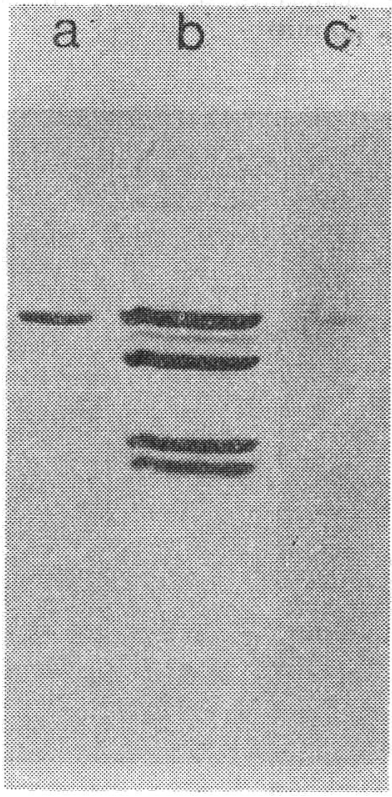

Fig. 16. Immunoreplica technique with antibody to vimentin. (a) shows purified murine vimentin, (b) cytoskeletal proteins purified from PtK2 cells, (c) immunoreplica with antibody to vimentin. (a)(c) are stained with coomassie blue. For further details see ref. ${ }^{86)}$

shown to specifically recognize vimentin in a crude cellular extract. When these antibodies are used in immunofluorescence microscopy, filaments of the type shown in Fig. 17 are specifically recognized.

2) Cytokeratin or prekeratin-type filaments. These are composed of 4 to 5 polypeptides of molecular weights between 45,000 and 68,000. When an tonofilament-like structures not only in cells such as keratinocytes, but also in epithelial cell lines including rat kangaroo PtK1 and PtK2 cells (Fig. 18) and in Hela cells. ${ }^{78,79)}$ They can also be identified in 


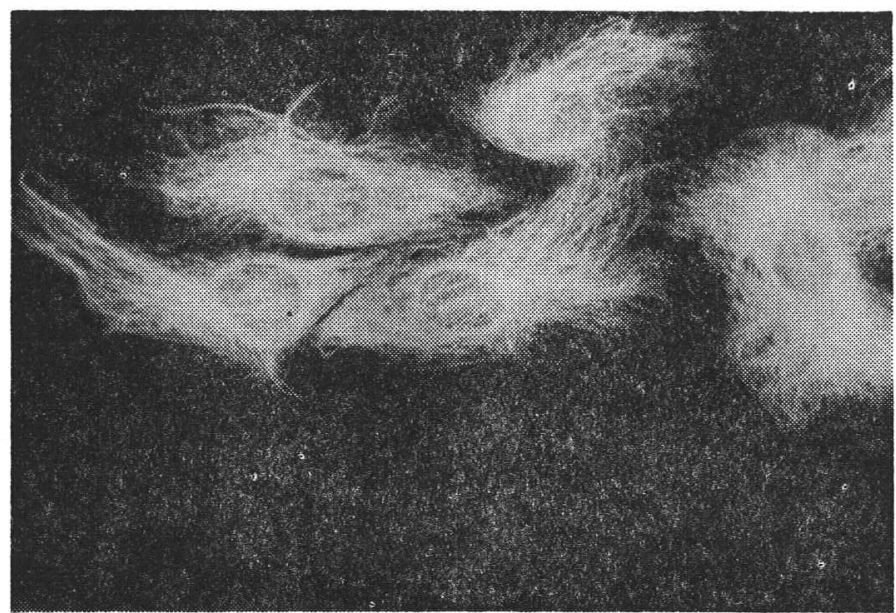

Fig. 17. Hamster NIL-8 cells stained with antibody to vimentin. Note the abundance of $100 \AA$ filaments. For further details see ref. ${ }^{75,76)}$

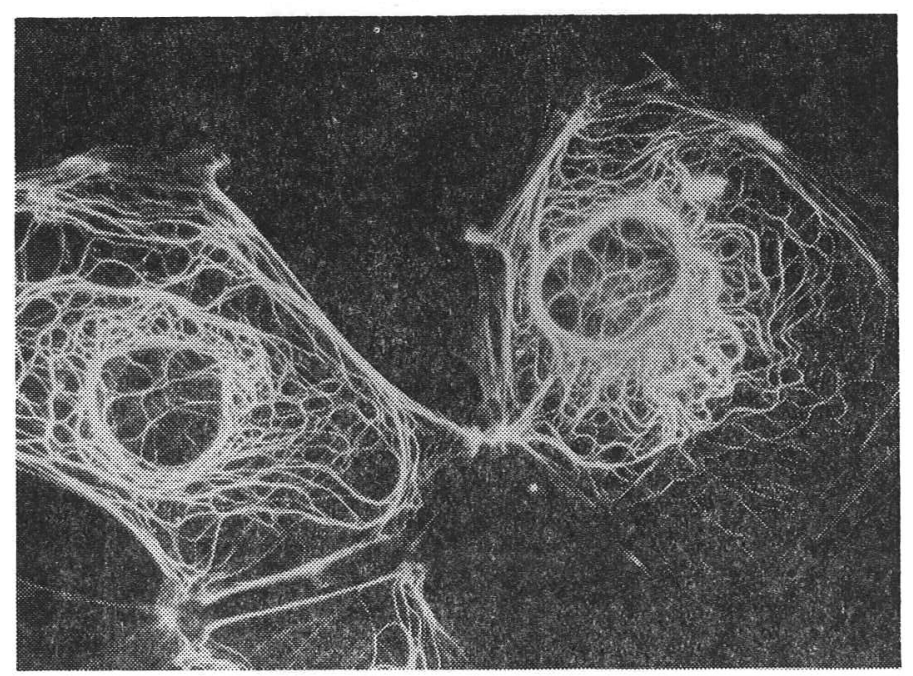

Fig. 18. Rat kangaroo PtK2 cells stained with antibody against prekeratin. which stains the cytokeratin type of intermediate filaments. For further details see ref. ${ }^{62,77,86)}$

tissue sections, ${ }^{77,79,80)}$ and Fig. 19 shows a section through rat tongue stained at the top with antibody to prekeratin which stains specifically the keratin filaments of the epithelium, and at the bottom with antibody to vimentin. In both cases different portions of the tongue are stained, again showing the specificity of the two antibodies. That the cytokeratin filaments form a cytoskeleton is shown in Fig. 20 for intestinal brush border cells and other epithelially-derived tissues that stain are illustrated in ref. ${ }^{75,79}$

3) Desmin ${ }^{81)}$ or skeletin ${ }^{82}$ filaments characteristic of muscle cells. The subunit has a polypeptide moleclar weight of 53,000 daltons. This protein can be identified in the z-line of skeletal muscle, in the intermediate filaments of smooth muscle, and in certain cell types in culture ${ }^{81}$ ) including some clones of BHK cells. ${ }^{83)}$ 


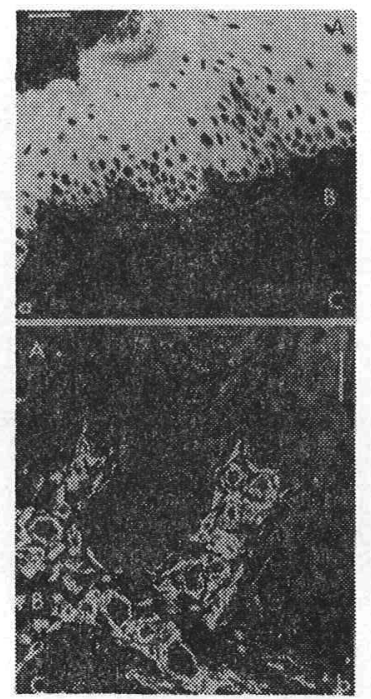

Fig. 19. Section through rat tongue stained either (a) with antibody to prekeratin or (b) with antibody to vimentin. Note the mutualy exclusive staining. For further details see ref. ${ }^{75)}$



Fig. 20. Cytoskeleton of intestinal brush border cells stained with antibody to prekeratin. For further details see ref. ${ }^{88)}$

4) Glial filaments. The purified protein subunit has a molecular weight of approximately 50,000 daltons. Antibodies can be raised to this subunit which specifically recognize only glial type filaments. ${ }^{84}$

5) Neurofilaments. Here the polypeptide composition is more complex and at least in some systems there is convincing evidence of polypeptides in the higher molecular weight range ${ }^{85)}$ (e.g. 155,000 and 200, 000 daltons).

A comparison of the polypeptide chain molecular weights of the different intermediate sized filaments is shown in Fig. 21. 


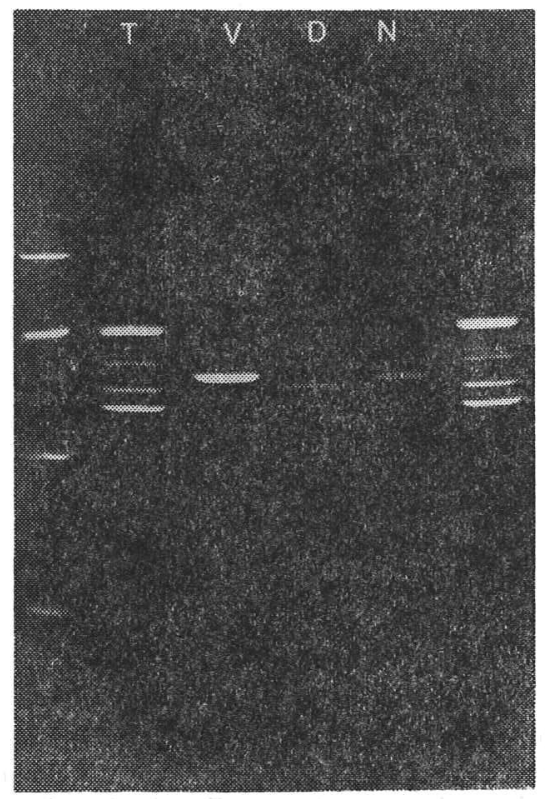

Fig. 21. Comparison of polypeptide molecular wieghts of the subunits of different types of intermediate filaments.

$\mathrm{T}:$ tonofilaments, i.e. intermediate filaments of the cytokeratin type, $\mathrm{V}$ : vimentin type, $\mathrm{D}:$ desmin type, $\mathrm{N}$ : glial filaments.

Note that the subunits of the different intermediate type filaments have different electrophoretic modilities on SDS gels.

There are two further points to be made about the $100 \AA$ filament proteins. First in our experience almost - cells replicating in culture have in addition to the system indicative of the tissue of origin the vimentin system, i.e. the vimentin system seems to be acquired at the same time as the cell acquires the ability to replicate in vitro. ${ }^{75,86)}$ Thus PtK2 cells contain both vimentin and prekeratin type filaments. ${ }^{86)}$ Other examples of cells in culture showing more than one kind of intermediate filament are shown in Table 6. Second, given the existence of specific antibodies that recognize a particular class of intermediate filaments, one can use these antibodies to type the tissue of origin. Thus in Fig. 22 one sees that Hela cells are stained by the prekeratin antibody, ${ }^{87)}$ indicating that these cells after many passages in culture continue to express the intermediate filament type characteristic of the epithelial tissue from which they were derived. Obviously in the future this type of approach may have medical applications. Equally, obviously one needs to know more about the biochemical basis for the immunological differences that are observed.

Table 6. Cells in culture that express more than one intermediate filament system.

\begin{tabular}{l|l|l}
\hline \hline \multirow{2}{*}{ Cytokeratin + vimentin } & PtK2, PtK1, MDCK & kidney epithelium \\
& Hela, ME-180 & cervix carcinoma \\
& KB & mouth carcinoma \\
& HEL & neonatal epidermis \\
& BMGE & alveola epithelium mammary gland \\
Desmin + vimentin & BHK-21 & fibroblastoid line, kidney \\
Glial & U-251 MG & glioma \\
\hline
\end{tabular}




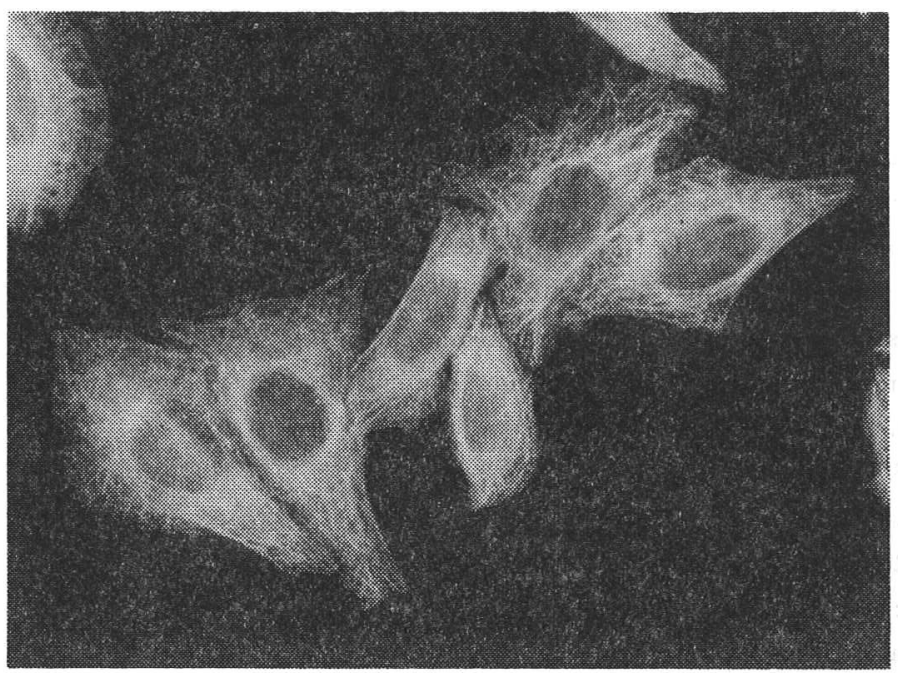

Fig. 22. Hela cells stained with antibody to prekeratin.

In summary I have tried to describe the current state of knowledge about the fibrous elements of the cellular cytoskeleton. I have obviously left vast areas uncovered. I have not discussed in any detail the function of these cytoskeletal elements, and have not approached the problem of how they are linked to each other, or to other elements such as the nucleus, the plasma membrane, or the external cytoskeleton. I hope you will forgive these omissions, but my purpose has been really not to provide an absolutely detailed account of cellular structure, but rather to show how relatively simple techniques - in this case SDS gel electrophoresis and immunofluorescence microscopy - can be used to provide new information.

I should also point out that in principle, immunofluorescence microscopy with specific antibodies can be used to locate any antigen in the cell which is associated preferentially with identifiable cellular structures. Thus obviously there are still many unexplored uses of this technique, both in cell biology and in medicine.

Finally I would like to congratulate the Japanese Society of Electrophoresis on the occasion of their thirtieth Anniversary, and also to thank the members of the Society not only for inviting me to address the Society, but also for listening to my talk which unfortunately I was not able to give in Japanese.

\section{Acknowledgement}

The text was completed in August 1979. It is a pleasure to acknowledge the collaborations with Klaus Weber and Werner Franke which made much of the work described in this article possible. I would also like to thank the Max Planck Gesellschaft for financial support.

\section{References}

1) Weber, K. and Osborn, M. : J. Biol. Chem., 244: 4406, 1969.

2) Shapiro, A. L., Vinuela, E. and Maizel, J.V. Jr. : Biochem. Biophys. Res. Commun., 43 : 367, 1967.

3) Weber, K. : Nature, $218: 1116,1968$.

4) Wiley, D.C. and Lipscombe, W.N. : Nature, $218: 1119,1968$.

5) Klotz, I.M., Darnall, D. W. and Langerman, N.R. : in "The Proteins" (Neurath, H. and Hill, R.L.eds.) Vol. 1, p. 292, Academic Press. 
6) Dunker, A.R. and Rueckert, R.R. : J. Biol. Chem., $244: 5074,1969$.

7) Laemmli, U.K. : Nature, $227: 680,1970$.

8) Maizel, J. V.Jr. : in "Methods in Virology" (K. Maramorosch and H. Koprowski, eds.) Vol. 5, p. 179, Academic Press, New York.

9) Studier, F. W. : Science, 176:367, 1972.

10) Swank, R.T. and Munkres, K.D. : Anal. Biochem., 39 : 462, 1971.

11) Weber, K. and Osborn, M. : in "The Proteins" (Neurath, H. and Hill, R.L. eds.) Vol. 1, p. 179, Academic Press.

Weber, K., Pringle, J. R. and Osborn, M. : in "Methods in Enzymology" (Hirs, C. M. and Timasheff, S. N. eds.) Vol. 26, p. 3, Academic Press, 1972.

12) Bretscher, M.S. : Nature New Biol., $231: 229,1971$.

13) Reynolds, J.A. and Tanford, C. : J. Biol. Chem., $245: 5161,1970$.

Fish. W. W., Reynolds, J. A. and Tanford, C. : J. Biol. Chem., 245: 5166, 1970.

14) Burgess, R. R. : J. Biol. Chem., $244: 6168,1969$.

15) Kamen, R. : Nature, $228: 527,1970$.

16) Blumenthal, T., Landers, T.A. and Weber, K. : Proc. Nat. Acad. Sci. U.S. A., 69: 1313, 1972.

17) Rosenbusch, J.P. and Weber, K. : J. Biol. Chem., 246: 1644, 1971.

18) Weeds, A. G. and Lowey, S. : J. Mol. Biol., 61:701, 1971 and other earlier references in this paper.

19) Davies, G.E. and Stark, G.R. : Proc. Nat. Acad. Sci. U.S. A., 66 : 651, 1970.

20) Osborn, M., Weiner, A. and Weber, K. : Eur. J. Biochem., i7:63, 1970.

21) Weiner, A.M. and Weber, K. : Nature New Biol., $234: 206$.

22) Butterworth, B.E., Hall, L., Stoltzfus, C.M. and Rueckert, R.R. : Proc. Nat. Acad. Sci. U.S.A., 68 : 3083, 1971.

23). O’Farrell, P. H. : J. Biol. Chem., $250:$ 4007, 1975.

24) Garrels, J.I. and Gibson, W. : Cell, $9: 793,1976$.

25) Kyte, J. : J. Biol. Chem., $246: 4157,1971$.

26) Weber, K. and Kuter, D. J. : J. Biol. Chem., $246: 4505,1971$.

27) Henderson, L. E., Oroszlan, S. and Konigsberg, W. : Anal. Biochem., 93 : 153, 1979.

28) Cleveland, D., Fischer, S., Kirschner, M. and Laemmli, U.K. : J. Biol. Chem., $252: 1102,1977$.

29) Weiner, A. M., Platt, T. and Weber, K. : J. Biol. Chem., 247 : 3242, 1972.

30) Neville, D. M. : J. Biol. Chem., $246: 6328,1971$.

Eckhardt, A.E., Hayes, C.E. and Goldstein, I. J. : Anal. Biochem., 73 : 1920, 1976.

31) Showe, M., Isobe, E. and Onorato, L. : J. Mol. Biol., $107: 55,1976$.

32) Saltzgaber-Müller, J. and Schatz, G. : J. Biol. Chem., $235: 305,1978$.

33) Platt, T., Weber, K., Ganem, D. and Miller, J.H. : Proc. Nat. Acad. Sci. U. S. A., 69 : 897, 1972.

34) See for example Cold Spring Harbor Symposium on Quantitative Biology, Vol. XXXIX, 1974.

35) Roberts, D. E. : J. Mol. Biol., $45: 221,1969$.

36) Lazarides, E. and Weber, K. : Proc. Nat. Acad. Sci. U.S. A., $71: 2268,1974$.

37) Osborn, M. and Weber, K. : Exp. Cell Res., 106:339, 1977.

Brown, S., Levinson, W. and Spudich, J. A. : J. Supramol. Struct., $5: 119$.

Lenk, R., Ramson, L., Kaufman, Y. and Penman, S. : Cell, 10:67, 1977.

38) Coons, A.H. and Kaplan, M.H. : J. Exp. Med., $91: 1$, 1950.

39) Goldman, R.D., Lazarides, E., Pollack, R. and Weber, K. : Exp. Cell Res., 90 : 333, 1975.

40) Ishikawa, H. R., Bischoff, R. and Holtzer, H. : J. Cell Biol., 43 : 312, 1969.

41) Pollack, R., Osborn, M. and Weber, K. : Proc. Nat. Acad. Sci. U.S. A., 72 : 994, 1975. 
42) Willingham, M.C., Yamada, K. M., Yamada, S. S., Pouyssegur, J. and Pastan, I. : Cell, 10 : 375, 1977.

43) Whalen, R. G., Butler-Browne, G. and Gros, F. : Proc. Nat. Acad. Sci. U.S. A., 73 : 2018, 1976.

44) Vandekerckhove, J. and Weber, K. : Proc. Nat. Acad. Sci. U. S. A., 75 : 1106, 1978.

45) Wang, K., Ash, J.F. and Singer, S. J. : Proc. Nat. Acad. Sci. U.S. A., 72 : 4483, 1975.

46) Weber, K. and Groeschel-Stewart, U. : Proc. Nat. Acad. Sci. U.S. A., 71 : 4561, 1974.

47) Lazarides, E. : J. Cell Biol., $68: 202,1976$.

48) Lazarides, E. : J. Cell Biol., $65: 549,1975$.

49) Gordon, W.E. : Exp. Cell Res., $117: 253,1975$.

Rathke, P.C., Osborn, M. and Weber, K. : Eur. J. Cell Biol., $19: 40,1979$.

50) Webster, R.E., Henderson, D., Osborn, M. and Weber, K. : Proc. Nat. Acad. Sci. U. S. A., 75 : 5511 , 1978.

51) Wolosewick, J. J. and Porter, K.R. : Am. J. Anat., 147 : 303, 1976.

52) Carter, S.B. : Nature, $213: 256,1967$.

Weber, K., Rathke, P.C., Osborn, M. and Franke, W.W. : Exp. Cell Res., 102 : 285, 1976.

53) Wieland, T. : Naturwissenschaften, $64: 303,1977$.

54) Wehland, J., Osborn, M. and Weber, K. : Proc. Nat. Acad. Sci. U.S. A., 74 : 5613, 1977.

55) Aubin, J.E., Weber, K. and Osborn, M. : Exp. Cell Res., 124:93, 1979.

55a)Schroeder, T.E. : in "Molecules and Cell Movement" (S. Inoue and R.E. Stephens, eds.) pp. 334-352, Raven Press, New York.

56) Sanger, J. W. : Proc. Nat. Acad. Sci. U.S. A., $72: 1913,1975$.

Fujiwara, K. and Pollard, T.D. : J. Cell Biol., $71: 848,1976$.

57) Mabuchi, I. and Okuno, M. : J. Cell Biol., $74: 25.1,1977$.

58) Weber, K., Pollack. R. and Bibring, T. : Proc. Nat. Acad. Sci. U.S. A., 72 : 459, 1975.

59) Frankel, F.R. : Proc. Nat. Acad. Sci. U.S. A., 73 : 2798, 1976.

60) Brinkley, B. R., Fuller, G. M. and Highfield, D. P. : Proc. Nat. Acad. Sci. U. S. A., 72 : 4981, 1975.

61) Weber, K. and Osborn, M. : in "Microtubules" (K. Roberts and L.S. Hyams, eds.) Academic Press, London and New York, 1979.

62) Osborn, M., Born, T., Koitzsch, H. J. and Weber, K. : Cell, 14:477, 1978.

63) Kuriyama, R. and Miki-Nomura, T. : J. Cell Science, $19: 607,1975$.

64) Osborn, M., Webster, R.E. and Weber, K. : J. Cell Biol., $72: 459$, 1978.

65) Osborn, M. and Weber, K. : Cell, $11: 512,1977$.

66) DeMey, J., Joniau, M., DeBrabander, M., Moens, W. and Geuens, G. : Proc. Nat. Acad. Sci. U.S.A., $75: 1339,1978$

Tucker, R. W., Sanford, K. K. and Frankel, F.R. : Cell, $13: 629,1978$.

67) Conolly, J.A., Kalnins, V.I., Cleveland, D. W. and Kirschner, M. : Proc. Nat. Acad. Sci. U.S. A., 74 : 2437, 1977.

68) Sherline, P. and Schiavone, K. : Science, 198: 1038, 1977.

Conolly, J. A., Kalnins, V. I.., Cleveland, D.W. and Kirschner, M. : J. Cell Biol., 76 : 781, 1978.

69) Osborn, M. and Weber, K. : Proc. Nat. Acad. Sci. U.S. A., 73 : 867, 1976.

70) Roberts, K. : Prog. Biophys. Molec. Biol., 28 : 371, 1974.

Osborn, M. and Weber, K. : Exp. Cell Res., $103: 331,1974$.

71) Fuller, G. M., Brinkley, B.R. and Boughter, M. J. : Science, 187 : 948, 1975.

Weber, K., Bibring, T. and Osborn, M. : Exp. Cell Res., $95: 111$.

72) See for example Starger, J.M., Brown, W.E., Goldman, A.E. and Goldman, R.D. : J. Cell Biol., 78 : 93, 1978. 


\section{（170）生物物理化学}

73) Bennett, G.S., Fellini, S.A., Croop, J.M., Otto, J. J., Bryan, J. and Holtzer, H. : Proc. Nat. Acad. Sci. U.S.A., 75: 4364, 1978.

74) Lazarides, E. and Balzer, D. R. : Cell, 14:429, 1978.

75) Franke, W. W., Schmid, E., Osborn, M. and Weber, K. : Proc. Nat. Acad. Sci. U. S. A., 75 : $5034,1978$.

76) Hynes, R. O. and Destree, A. T. : Cell, 13:151, 1978.

77) Franke, W.W., Weber, K., Osborn, M., Schmid, E. and 1978.

78) Sun, T. T. and Green, H. : Cell, 14:469, 1978.

79) Franke, W.W., Applehans, B., Schmid, E., Freudenstein, C., Osborn, M. and Weber, K. : Differentiation, $15: 7,1979$.

80) Sun, T. T., Shih, C. and Green, H. : Proc. Nat. Acad. Sci. U.S. A., $76: 2813,1979$.

81) Lazarides, E. and Hubbard, B. D. : Proc. Nat. Acad. Sci. U.S. A., $73: 4344,1976$. Lazarides, E. : Exp. Cell Res., 112:265, 1978.

82) Small, J. V. and Sobieszek, A. : J. Cell Sci., $23: 243,1977$.

Cooke, P. : J. Cell Biol., 68 : 539, 1976.

83) Tuszynski, G.P., Frank, E.D., Damsky, C. H., Buck, C.A. and Warren, L. : J. Biol. Chem., 254 : 6138, 1979.

84) Paetau, A., Virtanen, I., Stenman, S., Kurki, P., Linder, E., Vaheri, A., Westermark, B., Dahl, D. and Haltia, M. : Acta Neuropath. (Berl.), $47: 71,1979$.

85) Gilbert, D.S., Newby, B. J. and Anderton, B. H. : Nature, 256: 588, 1975.

Benitz, W.E., Dahl, D., Williams, K.W. and Bignami, A. : FEBS Letters, 96:159, 1976.

86) Osborn, M., Franke, W.W. and Weber, K. : Exp. Cell Res., 125 : 37, 1950.

87) Franke, W.W., Schmid, E., Weber, K. and Osborn, M. : Exp. Cell Res., 118 : 95, 1978.

88) Franke, W.W., Appelhans, B., Schmid, E., Freudenstein, C., Osborn, M. and Weber, K : Eur. J. Cell Biol., $19: 255,1979$. 